\title{
School Violence: A Cross Cultural Analysis
}

\author{
Camélia Dumitriu (Ph.D.) \\ University of Quebec at Montreal, (UQAM) Canada. \\ School of Business Sciences (ESG). \\ E-mail: dumitriu.camelia@uqam.ca
}

\section{Doi:10.5901/mjss.2013.v4n9p89}

\begin{abstract}
This research is part of an international project on disaster management planning for coping with acts of extreme violence in schools. The project was funded by the SSH Research Council of Canada and carried out by an academic team from University of Quebec at Montreal (UQAM). In this article, the author seeks to provide some insights on the matter of culture as a root-cause of school related violence, by conducting a cross cultural analysis of five school shooting events. The results show that some cultural factors at national/community/organizational level were among the root-causes of school's vulnerability to extreme violence. Further, these factors have played an important role in enhancing violence in schools and/or in delaying the intervention process. The results underline potentially critical cultural issues that relevant stakeholders - such as policy makers, educational institutions, communities, and families - should consider in order to proactively and effectively cope with new emerging risks related to extreme violence in schools.
\end{abstract}

Keywords: organizational culture; school violence; school shootings; Case study method.

\section{Introduction and definition of terms}

After 1990, some new social phenomena - such as 'work violence' and 'school violence' - have become subjects of concern for national governments. The term "school violence" refers to various forms of violent behavior on school property, such as acts of disrespect toward teachers; verbal violence; gang activities, bullying at school and cyberbullying, and; physical attack with a weapon. However, the roots and patterns of violent behavior in schools seem to be diversifying. In some universities, tenure-track professors killed the administrators who had denied them tenure. In some others, graduate students killed their thesis advisers. In other schools students killed classmates who, they claimed, had bullied them, or some of their teachers who, they maintained, had wronged them. Finally, some outsiders selected a specific school as a target and perpetrated a violent attack against its student population. All of these attacks took the form of a 'rampage shooting' and the tragic event is commonly known as "school shooting."

Dumitriu (2013) shows that, contrary to to the popular belief that "a crazed killer enters a school and starts shooting," only a few of the attackers were, in fact, diagnosed with a mental disorder. Moreover, in most of these cases, their mental illnesses were diagnosed only during the trial by retrospective assessments by physicians who testified at the proceedings. A school shooting is, in fact, a multiple-victim event and an act of extreme violence that is perpetrated on the school's premises, generally by a school-related perpetrator (student, former student, teacher or outsider who has ties to the school or its community) who carefully plans in advance his or her act (Dumitriu, 2013). The school that is confronted with such an event faces a crisis situation. Therefore, schools should prepare themselves to deal with stressful circumstances and respond to such organizational crises.

\section{Literature review}

Cameron (1981; 2005) discusses various analytical frameworks and models of organizational effectiveness and shows that, according to some of them, an organization is only effective to the extent that it reaches its goals and/or meets the expectations of its key stakeholders and various interest groups. According to some other frameworks, an effective organization is one that has distinctive capabilities to acquire resources. Finally, some other frameworks emphasize the role played by the consistency of the organization's internal functioning and its stability in improving its effectiveness. This author also reviewed some variables used by researchers to measure organizational effectiveness that are based either on structural factors (e.g., decision-making processes and job design) or on cultural factors (e.g., group cohesion, 
social justice, and culture). However, Cameron (2005, p. 4) concludes that "Complex and changing environments give rise to different appropriate effectiveness criteria than do stable and undemanding environments."

Even if researchers appear to agree that cultural factors have an impact on organization's effectiveness, and that they have a certain role in its adjustment to various disruptive factors in its external environment, there is no consensus on the definition of culture. The term 'culture' has numerous meanings. Kroeber et al. (1952) identified more than 160 definitions of culture in the literature. They include: (a) 'descriptive definitions' that make reference to culture as civilization, including "people's products and activities, social and religious order, customs and beliefs" (p. 81); (b) 'normative definitions' according to which culture comprises all of a community's standardized social procedures, traditions, and beliefs; (c) 'psychological definitions' in which emphasis is given to the capacity of the society, at a certain point in its development, to adjust to its environment to satisfy people's economic and social needs; (d) 'structural definitions' that deal with aspects related to social interactions and social systems, including the organizational culture and its subcultures, and; (e)'genetic definitions' that describe culture as a result of an interpretation of various artifacts.

With regard to these various definitions of culture and the relationships among them, Hofstede's model of cultural differences (2001) shows that nations and countries differ in five cultural dimensions that depend, to a certain point, on the societal culture of each country, but which also play an important role in shaping the organizational cultures in the respective country. According to Dimmock (2000), the various organizational cultures that are found in the educational system differ mainly in their practices and less in their values. He also emphasizes that the main difference between organizational and societal cultures lies in the fact that "membership of an organization is usually subject to some degree of choice, whereas the country and culture in which people are born and bred are decided for them."(p. 54). He further concludes that, in what concerns the educational system, it is easier to change an organizational culture then a societal culture, because the latter is "more enduring" and changes "only gradually over longer time periods."

There is very little research dealing with organizational factors and their relationship to school violence. Garrett et al.(2004) show that researchers who have examined the relationship between the school's size and its student behaviour "in terms of violence, bullying, suspensions or incidents" have obtained contradictory results. Similarly, Jensen (2004, p.643) concluded that "Despite the importance of cultural concepts in all sociological perspectives [...], there is very little research that is relevant to the empirical merits of these disparate views of the manner in which culture affects violence."

\section{Research Design and research method}

Ten schools that had experienced a school shooting incident were selected for in-depth qualitative case studies (Yin, 2003). First, data were collected from the strategic plans of these schools at the time of the event, as well as governmental reports of inquiries into these events, police reports, newspaper articles and archival documents. Then, field data were collected in six countries through semi-structured interviews and/or focus-groups. The respondents were key stakeholders: school administrators, teachers, and students; senior officials of the Ministry of Education and other government officials in various countries; psychologists and other healthcare professionals who assisted the victims after the tragic event; members of the emergency medical teams and law enforcement agencies who were directly involved in the intervention during these events.

\section{Findings}

\subsection{Case 1: Monash University (Australia) versus Virginia Tech (USA)}

Australia is a multi-ethnic and liberal society, in which more than 200 languages and dialects are spoken. Australians are described as "open minded", very casual, and friendly. Also, although the great majority of the population is of European descent, Australian culture is very similar to American and British cultures, with English as its official language.

\subsubsection{The organizational culture}

Prior to the event, Monash University had experienced very rapid growth, as a result of many direct investments abroad (Table 1). This had an immediate impact on its organizational culture, which has become very "performance-driven" and very heterogeneous. 
Table 1: Monash University: Growth strategy (2002)

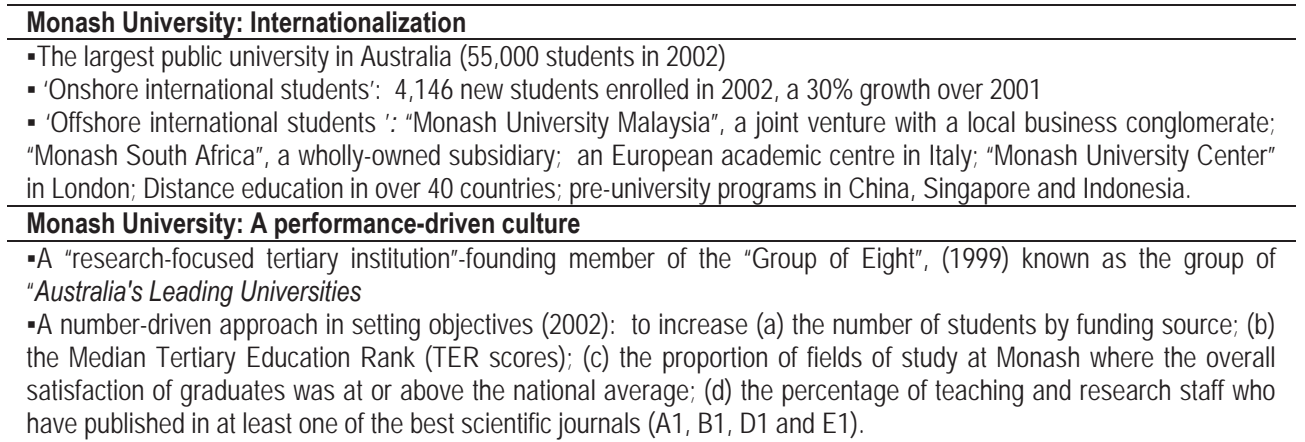

Source: Monash University strategic plan (2002) and public documents of the Ministry of education

The new values embedded in the university's organizational culture, such as high academic standards, internationalization, and aggressive competitiveness subjected professors and students to a great deal of pressure as they were required to continuously perform better. Thus, they appeared to have become more individualistic individuals, who were "obsessed with performance" and preoccupied mainly with their individual goals and needs. As a result, they paid less attention to others, especially international students who were newly established in Australia. This subtle change in culture does not apply uniquely to Monash University, but also to other large research universities that strive to obtain a "place on the podium." The international ranking agencies that assess the quality of educational services offered by schools and universities use "the podium model" (Van Parijs, 2008) according to which "ranking high in terms of the scores constructed . . . is immediately interpreted as belonging to the 'top,' 'best,' 'greatest' universities in the world." (p. $6)$.

Also, like any large public university, Monash was under extreme pressure from competitors and the government. Accordingly, the university endeavoured to attain ambitious goals (Table 1), while conciliating the competing demands and needs, but neglecting some related social aspects. Many of the foreign students who were enrolled on its Australian campuses struggled to cope with the high academic standards imposed by Monash, while confronting social stresses related to their integration in a new economic, cultural and social context. One of their greatest difficulties was becoming proficient in English. Monash University established a Language and Learning Service. However, the number of international students was increasing at such a rapid pace that this center could no longer cope with the increasing demand for assistance (Rees, 2002). On October, 21, 2002, a Chinese graduate student, who was teased relentlessly by his colleagues for his lack of proficiency in English and who had become very frustrated because students and teachers did not understand his oral presentations, climbed onto his desk on the day on which his oral presentation was scheduled and begun to shoot at students and teachers, shouting "You never understand me!"(Rees, 2002)

Virginia Tech University faced a similar situation in 2007, when a student of Asian origin killed 32 persons. He had been suffering from selective mutism, a certain type of autism disorder that prevents a person from properly communicating in organizational settings and public situations. However, a majority of individuals who are affected by this mental disorder perform at or above average and, according to medical opinion, are not expected to pose a danger to themselves or others. However, Cho begun to show signs of aggressive behavior at school and was referred to Cook Counseling Center, a Virginia Tech dedicated unit that provided mental health services to students and staff. He asked for help from practitioners at this medical center, but was met with the indifference that prevailed in that organization at that time. The report of inquiry into the shootings has strongly criticized the staff at Cook Counseling Center for their lack of intervention. After the shootings, the police found a note in his dorm room, stating, "You caused me to do this." (Potter et al., 2007) Like Monash University, Virginia Tech was a research university that was on a 'rapid growth' path. When the shootings occurred, the main objectives that were stated in its strategic plan were to implement new technologies and to "increase doctoral numbers, expand graduate degree offerings, increase competitiveness and diversity and international offerings." (Virginia Tech, Strategic Plan 2006-2012). However, no specific objectives were stated with regard to the Cook Counseling Center. 


\subsubsection{The national culture}

Another common feature of these two cases - Monash University and Virginia Tech - was that a student of Asian descent encountered specific difficulties in the university located in the host country- despite being a resident of the respective country and, supposedly, having had sufficient time to adapt to its culture. These difficulties could eventually be explained by the differences that exist between his native country and the host country, in national culture, as they are measured by the Hofstede's (2001) model (Figure 1).

Individualism (IND): in each of these two cases, the attack was perpetrated by an Asian student who had been a hard-working student and who had not shown signs of serious violent behaviour prior to the attack. Both the USA and Australia score high on the 'Individualism' dimension of national culture (such as this dimension is defined by Hofstede, 2001). Indeed, they are individualistic societies, in which individuals (a) are self-centered; (b) focus on individual achievement rather than integrating in groups, and; (c) do not avoid confrontational situations. In these societies, personal privacy is respected and embodied within the cultural norms. In contrast, South Korea and China score low on this dimension because they are 'collectivist' societies in which the most important personal goal of an individual is to belong to a certain group, often at the cost of sacrificing personal privacy. Group achievement is more highly valued than personal achievement and confrontational situations are avoided.

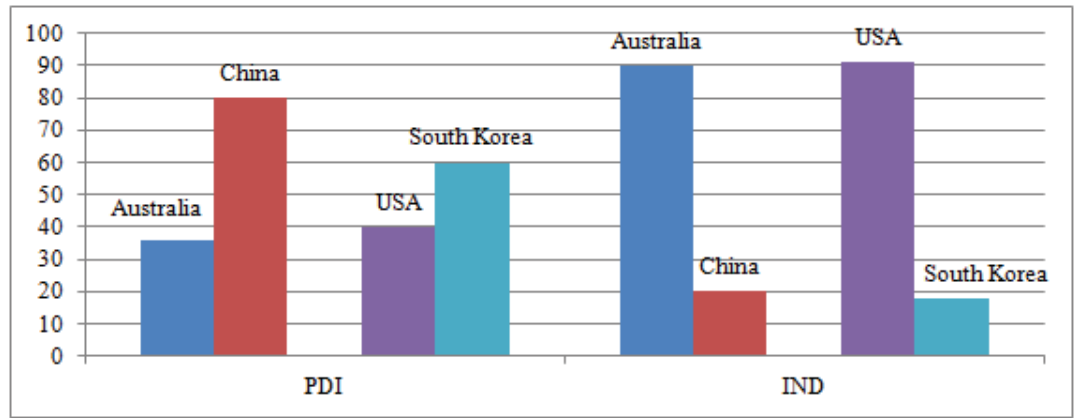

Figure 1: Cultural differences between the shooter's native country and his host-country

High versus low Power Distance (PDI): both shooters grew-up in countries with national cultures that score high on the 'Power Distance' dimension. In these societies, people accept that power in society is distributed unequally (within the family, school, firm, etc.); social status is important and; respect for "power" shapes relationships among individuals (child-parent; student-teacher; employee-employer). Clemans et al. (2012) found that high authority-directed respect is positively correlated with lower levels of aggression and 'social manipulation.' In contrast, the United States and Australia have national cultures that score low on this dimension. The power is distributed more equally and the relationships with the authority figures (parents, teachers, employers) are informal and based on 'social equality' rather than obedience and authority-directed respect.

\subsection{Case 2: The Islas Malvinas Middle School (Argentina)}

"Escuela 202 Islas Malvinas" is a public school in Carmen de Patagones, a small, tranquil city (30, 000 people) in Buenos Aires district where, according to some inhabitants, "almost nothing ever happens." With its churches and fortifications that date back to the $18^{\text {th }}$ century, and its "street of the canyons," the city is a symbol of Latin America's history.

Before 1990, the Argentinean educational system was rather centralized. However, it underwent great transformation in the 90s, and new laws have come into effect that called for the transfer of some responsibilities regarding educational services to the provinces. Accordingly, both authority and responsibility for educational services were further decentralized to the school level. Thus, schools were allowed to make their own decisions on certain issues, such as their organizational structure, the organization of the school day and learning hours, the choice of teaching modules and the group of teachers who were responsible for them as long as the curricula established by the province was observed. Soon after, Argentina's schools began to experience high rates of violence, such as aggressive behaviour among students and attacks against teachers. Two months before the event, the department of education (Buenos Aires 
province) sent a memo to some schools to warn of the rising number of violent acts perpetuated in schools. However, according to some of our interviewees, Islas Malvinas Middle School was not among the schools that had been notified of these concerns.

At Islas Malvinas Middle School, classes began at 7: 30 AM each day. On September 28, 2004, a 15 year old student, entered his classroom where his 29 classmates were waiting for the arrival of the teacher of their Human Rights course. Suddenly, the student began to shoot at his classmates. When he stopped firing to reload his gun, another student immobilized him. The police subsequently discovered three sentences written on his desk at school: "lies are the basis for the happiness of men," "if anyone has found the meaning of life please write it here," and "the most sensible thing we, humans, can do, is to commit suicide" (according to our interviewees - police and courts that ruled on this case).

The analysis performed in this study showed that Islas Malvinas School (2004) had adopted a "laissez-faire" culture. According to the lawyers who represent parents in their legal action against the school (which is still an ongoing process), the tragic event was the result of the "lack of discipline and control" in the school. At the meeting organized by the school following the shootings, the parents claimed that teachers and school management had been negligent, and blamed teacher CR of not being in class when his course was scheduled to begin. Moreover, the psychologists who assisted the students immediately after the shootings were strongly critical of the school: "The adults [teachers and supervisors] said that they had been there and did this and that, but when one listened to the boys, they were alone. [...]. The teacher was not in class and had not arrived ... it was said that the shots were heard so that children across the school came running, and they even entered classrooms to ask teachers to come and help. However, no one came. This was terrible. A terrible aspect is that at the school meeting that we held in order to share our findings, the teachers did not assume their share of responsibility." (interviews; translated from Spanish). Some school officials, whom our research team interviewed, admitted that the school staff commited many errors at that time and that "teachers were preoccupied mainly with their jobs and their own goals, and paid little attention to the children." Finally, according to others, this event was the result of a process of transformation that affected Argentinian society in the early 1990s. "We do not listen to others. We do not respect others' opinions. The only way in which we express ourselves is by aggression, [...] individualism, and an attitude of non-involvment'- said IR (interviews; translation from Spanish).

\subsection{Case 3: The Columbine High School (USA)}

In Columbine, where a school shooting occurred in 1999, 37 percent of the population over 25 years of age held a Bachelor's Degree or higher. More than 40 percent of the inhabitants were managers and professionals and about 20 percent of the households had an annual income of $\$ 100 \mathrm{~K}$ or more (U.S. Census Bureau, 2000).

The Columbine High School is an upper-middle-class suburban school. When the school shooting occurred, one of the first priorities of the school had been the achievements that its students obtained in athletic competitions. The analysis revealed that the organizational culture of Columbine High School (1999) was dysfunctional in its group dynamics, because it seemed to favor a certain "elite" (students who achieved exceptional athletic performance) - a fact that was a major stress factor for other students who did not possess such athletic abilities, including the shooters themselves. Another feature of Columbine's culture was its tolerance of verbal and physical violence; racist taunts; students' odd appearance (students wearing odd clothes); and violent writings (Dumitriu, 2013). As in all organizations, this culture was propagated by various values, rites, artifacts, and symbols. Sports trophies were displayed inside the school in the most visible areas. Further, in the school yearbook, the quality of the paper displaying sporting events and athletes' photos was better than that devoted to academic events. Long before the tragic event, students and parents had complained that "athletes" teased others students and enjoyed many privileges in school that were not available to others. For example, one particular wrestler was permitted "to park his $\$ 100,000$ Hummer all day in a 15-minute space." (Adams and Russakoff, 1999). School administrators did not consider these repeated complaints. Perhaps as a result, some students formed their own organization ("Trench Coat Mafia") "to give themselves a sense of belonging in the face of teasing and bullying by other students, especially athletes." 1 This organizational culture contributed to widening the gap that was being created between the different groups of students in the school. Four main groups have been identified in this study (Figure 2).

- The Popular Student' group: the most important values of those in this group (also known in American folklore

1 Jefferson County's Sherriff Bureau. Report on Columbine Shootings. Chapter "The Intervention". Paragraph "The Trench Coat Mafia". 
as "cool people") were "being liked" and "being popular." These students were perceived by their classmates as opinion leaders, and not necessarily for their academic grades or achievements in sports, but rather for how they walked, spoke, danced or acted in their day-to-day activities and for the clothes they wore or the car they drove, etc.

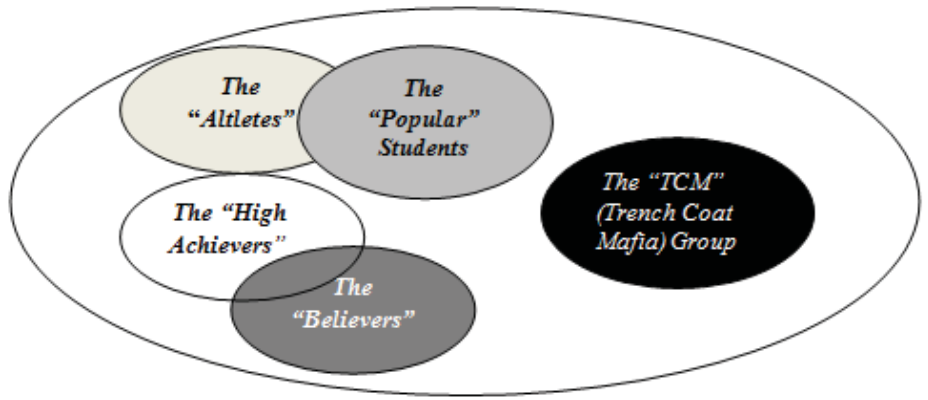

Figure 2: The Columbine High School (1999): group dynamics as root of school violence

- The Believers: for students in this group, the religious values were essential in their lives. Some of them volunteered for religious organizations, others never left their Bible at home and, finally, others composed religious poems. This group was representative of the community in which this school is located. In an article published by Time Magazine (US \& CNN) in May 9, 1999 reporter Nancy Gibbs described Colorado as being "the heart of America's evangelical community, home to the Promise Keepers, James Dobson's Focus on the Family and vast and growing mega churches." let us remind the readers that Colorado is described as being "the heart of America's evangelical community, home to the Promise Keepers, James Dobson's Focus on the Family and vast and growing mega churches" (Nancy Gibbs, 1999).

- The Athletes: this group was formed by students who performed exceptionally in sports or athletics

- The High Achievers: the main values shared by the students of this group were not related to popularity or religion stewardship, but instead to achievements that they sought in some specific activities (either academic or specific extracurricular activities). As some military bases were located in that area, some students of this group dreamt of a military career, while others simply wanted to follow in their parents' footsteps and work for the United States Armed Forces.

- The TCM Group: "Trench Coat Mafia" emerged as a balancing counter-force to the school's other groups. Its members were often teased or bullied by students in other groups, especially the Athletes, and felt marginalized. They wore black trench coats, played extensively violent video games, admired the "NAZI culture" and wore clothes with Nazis symbols. They were described by some of their classmates as "computer-savvy," but also as individuals who "disliked minorities and made derogatory remarks about Hispanics and blacks."(Paulson, 1999).

Two of the members of the latter group decided to initiate a school shooting and targeted specific members in other groups at school. As one Columbine student explained, "With all the animosity among the various social groups at Columbine, something like this was bound to happen." (Weinhold, 2000).

\subsection{Case 4: The Nickel Mines Amish School}

The Amish have limited contact with the outside world and have adopted values related to a rural, religious, and simple life while striving to maintain religious purity. According to "Gelassenheit" (the core principle of the Amish social structure and values system), each community member must surrender to "God's will" and embrace a set of values that include simplicity, non-violence, forgiveness and humility, while rejecting the "English community's" values, such as modernism, worldliness and sophistication (Byers, 2008). Zehr et al. (2005) emphasize that many habits of their everyday life, like wearing plain conservative clothing and using horse-drawn buggies as their preferred mode of transportation, convey these values. The intricacies of family, seclusion (from the outside world), school particularities, hard work and religion appear to best represent the Amish way of life. Zehr et al. $(2005$, p. 60) illustrate these cultural constancies of the Amish 
culture by the "separation of boys and girls in the school cloakroom" and the "seating arrangement when the Amish meet to worship in their homes".

The 'Amish school' is generally a one room schoolhouse where children between ages 6 and 14 (the "scholars") are taught together by a young female teacher. Older scholars are often tutors for younger scholars and parents may assist in the classes without prior scheduling. Thus, an Amish school is very different from a large public school, where various conflicts may arise among different groups of students or between students and some teachers. An Amish school is more like a "gated community" where everyone knows everyone and where all of the members, students and teacher, share the same values. Not only does the teacher know each "scholar," but she also knows his/her parents, and his or her brothers and sisters who often attend the same school at the same time. Accordingly, strangers are unable to enter the school without being noticed.

However, on October 2, 2006, Charles Carl Roberts, a non-Amish, local milk truck driver entered the school in which 15 boys, 11 girls, a teacher and some female visitors were present. He then freed the visitors and the Amish boys and shot the girls, killing five and wounding the others before committing suicide. He had been a devoted Christian, the son of a police officer and a "perfect father" of three children. In the suicide note found in his home, he explained that the death of his infant daughter, Elise, in 1997, had changed his life forever by creating an "unimaginable emptiness" that left him "filled with so much hate towards himself and God." Neither the police team who managed the intervention at the Amish school, nor the Amish spokesperson- both of whom were interviewed by our research team - could explain this tragic act or the shooter's motive. However, the fact is that Roberts was "filled with anger towards God who had taken his daughter from him." He might have decided to get "revenge" on God by shooting the Amish girls, who were perceived by him as a symbol of a very religious community.

\section{Concluding remarks}

The analysis of these cases revealed that cultural factors have an impact on school violence. The vulnerability of the school to violence-related risks and the magnitude of the impact of these risks depend on numerous culture-related factors, such as:

- the "social heritage or tradition" (e.g., the differences between the "cultural heritage" of the perpetrator that was acquired in his native country, and the national culture of the host-country; (Monash University and Virginia Tech are such examples);

- the "material culture" of the school and some normative factors, such as goals, rules and regulations guiding administrators, and; patterns of the decision making process (strategy and structure): all the schools analyzed;

- $\operatorname{artifacts~(e.g.,~the~Columbine~school~case);~}$

- the "subjective culture" - shared beliefs, values and assumptions, including religious issues (the case of the Amish school), and;

- group dynamics, inter-group conflict and sub-cultures in the school (e.g., the case of the Columbine high school).

The results also suggest that educational systems that have undergone rapid decentralization of the decision making process are more susceptible to school violence during the transition period (from a centralized to a decentralized system), especially when the transition process is rapid or not well planned in advance.

Also, the results suggest that school violence-related risks may be greater for schools that adopt a rapid growth and a market-oriented culture and have not established specific structures to help students and staff to cope with the rapid change that they have initiated. These results support those of Simons (1999) who showed that organizations experiencing rapid growth are more vulnerable to various risks immediately after the expansion period, unlike counterparts that adopt an incremental approach to expansion. This is partly because the extreme pressure of struggling to support rapid growth sometimes leads to a neglect of key aspects and, in turn, new risks can emerge.

\section{References}

Adams, L., \& Russakoff, D. (1999, June 12). Dissecting Columbine's cult of the athlete. Washington Post, p. A1.

Akiba, M.; LeTendre, G.K.; Baker, D.P.; Goesling, B. (2002). Student Victimization: National and School System Effects on School Violence in 37 Nations. American Educational Research Journal, volume 39 (4), 829-853.

Birkman, J.(2006). Measuring vulnerability to promote disaster-resilient societies: Conceptual frameworks and definitions. In Birkman, J.

2 TLC TV Channel News, November 2, 2006. 
(ed.), Measuring Vulnerability to Natural Hazards - Towards Disaster Resilient Societies (pp. 9-54). NewYork: United University Press.

Byers, B. D. (2008). Amish Victimization and Offending: A rural subculture's experiences and responses to crime and justice. Southern Rural Sociology. 23(2), 226-251.

Cameron, K. (2005). Organizational Effectiveness: Its Demise and Re-emergence through Positive Organizational Scholarship (research report). Michigan : Center for Positive Organizational Scholarship. Retrieved from

http://www.bus.umich.edu/positive/PDF/Cameron-OE\%20and\%20POS.pdf (March, 22, 2013).

Clemans, K.H., Graber, J.A., \& Bettencourt, A.F. (2012). Adult-Directed and Peer-Directed Respect for Authority: Relationships with Aggressive and Manipulative Behavior. Journal of Research on Adolescence, 22(3), 480-486.

Dimmock, C.A. (2000). Designing the Learning-Centred School: A Cross-Cultural Perspective. Taylor \& Francis : West Sussex.

Dumitriu, C. (2013). Crisis Management in School Shootings Situations. The School - A Forgotten Factor in the Equation. In Böckler, N., Seeger, T., Sitzer P., \& Heitmeyer, W. (Eds.), School Shootings: International Research, Case Studies, and Prevention (pp. 441476). New York: Springer.

Dumitriu, C., \& Donia, M. (2009b). Crisis management: The case of school shootings: The Columbine High School Case. (research report). Montreal: UQAM. National Library and Archives Canada.

Garrett Z., Newman M., Elbourne D., \& al. (2004). Secondary School Size: A Systematic Review (research report). London: EPPICentre.

http://eppi.ioe.ac.uk/cms/LinkClick.aspx?fileticket=u9LVD2UJU34\%3D\&tabid=777\&mid=1829

Gibbs, N.(1999, May 17). Noon in the Garden of Good and Evil: The Tragedy at Columbine Began As a Crime Story But Is Becoming a Parable. Time, May 17, 153:54.

Hofstede, G. (2001). Culture's consequences: Comparing values, behaviors, institutions, and organizations across nations (2d ed.). Thousand Oaks, CA: Sage

Jensen, G. F. (2007). Social Learning and Violent Behavior. In Flannery, D., Vazonsyi, A., \& Waldman, I. (Eds.), The Cambridge Handbook of Violent Behavior and Aggression (pp. 636-646). New York: Cambridge University Press.

Kroeber, A. L., Kluckhohn, C., \& Untereiner, W. (1952). Culture: A Critical Review of Concepts and Definitions. New York: Vintage Books.

Paulson, S.,K. (1999 April 22). Student group had a dark lifestyle. Associated Press. Retrieved from http://web.dailycamera.com/shooting/22trench.html (October 15, 2008).

Potter, N., Schoetz, D., Esposito, R., \& Thomas, P., (2007, April 17). Killer's note. ABC News. Retrieved from http://abcnews.go.com/US/story?id=3048108\&page=1. (January 18, 2009).

Rees, M. (2002, October 29). Two students killed in Australian university. World Socialist. Retrieved from http://www.wsws.org/articles/2002/oct2002(January 11, 2009).

Simons, R. (1999, May). How risky is your company? Harvard Business Review, May, pp. 99-111.

Van Parijs, P. (2008). European higher education under the spell of university rankings. Ethical perspectives, 16(2), 189-206.

Weinhold, B.K. (2000). Uncovering the hidden causes of bullying and school violence. Counseling and Human Development, 32(6), 118..Retrieved from http://findarticles.com/p/articles/mi_qa3934/is_200002/ai_n8895278/ (May 1, 2009).

Yin, R. K. (2003): Case study research: Design and methods (3rd ed.). Newbury Park, CA: Sage

Zehr, H., Moss, G., \& Nichols, J. (2005). Amish Teacher Dialogues with Teacher Educators: Research, Culture, and Voices of Critique . The Qualitative Report. 10 (3), 593-620. 